\title{
REPRESENTASI KELUARGA DALAM KONTEKS HUKUM ISLAM
}

\author{
Oleh: Anung Al Hamat \\ anung.alhamat@gmail.com \\ (Dosen Tetap pascasarjana Universitas Ibn Khaldun Bogor)
}

\begin{abstract}
The family is built from the ties between two different beings and then be allied in a marriage. Marriage oriented to form a sakinah family, which is based on love and affection. Marriage is a strong commitment between fellow brides. The family is in human experience.

In relation with Islamic law, the family has a strategic position. Legal arrangements for individuals and families are closely linked to the awareness and religious adherence of each Moslem. With the formation of a family, it will automatically rise a law in it. Where this law contains a rule that is charged to all family members.

There are several inherent goals in each marriage those are (1) justifying the sexual relationship to satisfy the intent of human character, (2) realizing a family with the basis of love, love and (3) obtaining a legitimate generation.

Family has a very important function in individuals forming. Therefore, the whole function must be kept in mind. If one of these functions does not perform, so there will be disharmony in the system of rule in the family.
\end{abstract}

Keyword: Family, Islamic law.

\section{A. Pendahuluan}

Kehidupan manusia tidak dapat lepas dari apa yang disebut keluarga. Keluarga merupakan sentral dari kehidupan manusia; dari keluarga itulah manusia membina dan membangun generasi; dari keluarga itulah masingmasing memiliki rasa tanggung jawab untuk melakukan tugasnya sebagai anggota keluarga; dari keluarga itulah rasa agama dan keagamaan dapat dibina dan dibangun.

Keluarga dalam pandangan Islam mempunyai arti yang tidak kecil. Bahkan Islam menaruh perhatian besar terhadap kehidupan keluarga dengan meletakkan kaidahkaidah yang arif guna memelihara kehidupan keluarga dari 
ketidakharmonisan dan kehancuran. Keluarga adalah batu bata pertama untuk membangun istana masyarakat muslim dan merupakan madrasah iman yang diharapkan dapat mencetak generasi-generasi muslim yang mampu meninggikan kalimat Allah.

Hukum Islam merupakan salah satu pilar yang sangat penting dalam agama Islam. Tidak dapat dipungkiri lagi bahwa hampir di semua sendi kehidupan, baik dalam lingkungan ibadah maupun muamalah diatur dan dikondisikan sedemikian rupa oleh hukum Islam. Hukum Islam akan dapat memainkan perannya dengan baik dan tetap sesuai dengan sifat serta karaktristiknya jika mampu mengikuti perkembangan hukum manusia yang selalu berubah dan berkembang.

Dalam kaitannya dengan hukum Islam, keluarga mempunyai posisi yang sangat setrategis. Penataan hukum bagi pribadi dan keluarga sangat terkait dengan kesadaran dan ketaatan beragama setiap muslim. Dengan terbentuknya sebuah keluarga, maka akan secara otomatis melahirkan sebuah hukum di dalamnya. Di mana hukum ini berisi sebuah aturan-aturan yang dibebankan kepada semua anggota keluarga.

\section{B. Pembahasan}

Untuk lebih fokus dan sistematisnya makalah ini, maka pada pembahasan ini penulis akan mengkaji tentang: 1) Batasan Pengertian Keluarga dalam Konteks Hukum Islam, 2) Konstruksi Keluarga dalam Konteks Hukum Islam, 3) Fungsi Keluarga dalam Konteks Hukum Islam.

\section{Batasan Pengertian Keluarga}

Keluarga dalam bahasa Arab disebut ahlun, selain kata ahlun kata yang memiliki arti keluarga aali, 'asyirah, dan qurbaa. Kata ahlun berasal dari kata ahila yang berarti senang, suka, atau ramah. Menurut pendapat lain, kata ahlun berasal dari ahala yang berarti menikah (Ahmad Mukhtar Umar, 2008: 135).

Hamzah Ya'qub (1983:146) menyebutkan; keluarga adalah persekutuan hidup berdasarkan perkawinan yang sah dari suami dan istri yang juga selaku orang tua dari anak-anaknya yang dilahirkan. 
Dalam al-Quran kata ahlun disebutkan sebanyak 227 kali. Dari penyebutan sebanyak itu, kata ahlun memiliki tiga pengertian, yaitu: (Waryono Abdul Ghafur, 2006: 320).

a. Yang menunjuk pada manusia yang memiliki pertalian darah atau perkawinan, seperti ungkapan ahlu-bait atau seperti dalam ayat yang dibahas ini. Pengertian ini dalam bahasa Indonesia disebut keluarga.

b. Menunjuk pada suatu penduduk yang mempunyai wilayah-geografis atau tempat tinngal, seperti ucapan ahlu yatsrib, ahlu al-balad dan lain-lain. Dalam bahasa sehari-hari disebut warga atau penduduk.

c. Menunjuk pada status manusia secara teologis, seperti ahlu al-dzikr, ahlu al-kitab, alhu al-nar, ahlu aljannah dan sebagainya.

Meskipun tampak adanya perbedaan, namun ketiganya sebenarnya terkait, yakni ahlu yang berarti orang yang memiliki hubungan dekat, baik karena perkawinan, satu kampung, kampus, negara, atau satu agama. Terjalinnya hubungan kedekatan itu menjadikan pergaulan diantara mereka hidup dengan suka cita, senang dan damai.

Menurut ahli antropologi, keluarga merupakan suatu kesatuan sosial yang terkecil yang dipunyai manusia sebagai makhluk sosial. Hal ini didasarkan atas kenyataan bahwa keluarga merupakan satuan kekerabatan yang bertempat tinggal dan dilandasi oleh adanya kerjasama ekonomi, mempunyai fungsi untuk berkembang biak, mensosialisasikan atau mendidik anak, menolong serta melindungi yang lemah, khususnya merawat orang tua yang sudah jompo (Wahyu Ms, 1986: 57).

Menurut konsep Islam, keluarga adalah satu kesatuan hubungan antara laki-laki dan perempuan melalui akad nikah menurut ajaran Islam. Dengan adanya ikatan akad pernikahan tersebut dimaksudkan anak dan keturunan yang dihasilkan menjadi sah secara hukum agama (Aunur Rahim Faqih, 2001: 70).

Abu Hamid (1991: 87) mengatakan bahwa dalam hidup dan kehidupan seseorang tidak akan bisa lepas dari keluarga, karena disinilah permulaan kehidupan sosial seseorang berlangsung. Keluarga merupakan unit terkecil 
dari masyarakat. Sebagai kelompok kecil dalam masyarakat, keluarga terdiri menjadi dua, yaitu (Mufidah Ch, 2008: 40);

a. Kelurga kecil (nuslear family): keluarga inti adalah unit keluarga yang terdiri dari suami, isteri, dan anak-anak mereka, yang kadangkadang disebut juga sebagai conjugal family.

b. Keluarga besar (extended family): Keluarga besar didasarkan pada hubungan darah dari sejumlah besar orang, yang meliputi orang tua, anak, kakek-nenek, paman, bibi, kemenekan, dan seterusnya. Unit keluarga ini sering disebut sebagai conguine family (berdasarkan pertalian darah).

Menurut Robert R. Bell (1979) ada tiga jenis hubungan dalam keluarga:

a. Kerabat dekat (conventional kin), yaitu kerabat dekat yang terdiri dari individu yang terkait dalam keluarga melalui hubungan darah, adopsi, dan atau pernikahan, seperti suami-istri, orang tua, anak, dan antar saudara (siblings).

b. Kerabat jauh (discretionari kin), yaitu terdiri dari individu yang terikat dalam keluarga melalui hubungan darah, adopsi atau pernikahan, tetapi ikatankeluarganya lebih lemah dari pada kerabat dekat.

c. Orang yang dianggap keluarga (fictive kin), seorang yang dianggap kerabat karena adanya hubungan yang khusus, misalnya hubungan antar seseorang yang akrab.

Berkenaan dengan hubungan dalam keluarga, alQuran menyebutkan 'keluarga' dengan lafadh, yang antra lain عثبرة - قربى - أهل . Adapun pengertian dari lafadh tersebut disebutkan:

a. أهل / Ahlun

Al-Raghib (hal: 37) menyebutkan ada dua Ahlun: Ahlu al-Rajul dan Ahlu al-Islam, أهل الرجل adalah keluarga yang senasab seketurunan, mereka berkumpul dalam satu tempat tinggal, ditunjukan dengan ayat:

$$
\text { قو أنفسكم وأهليكم نارا (التحريم: 7) }
$$


Pada ayat ini Shawi (4, hal: 290) menyebutkan 'ahli' tersebut adalah astri dan anak-anak serta yang dikaitkan dengan keduanya.

Sedangkan أهل الإسلام adalah keluarga yang seagama, ditunjukkan pada ayat:

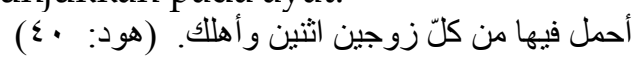

Pada ayat tersebut Shawi (2, hal: 268) menjelaskan, keluarga yang dimaksud ialah seorang istrinya yang iman bernama Aminah dan anak-anaknya yang iman, sementara seorang istrinya lagi yang kafir dan anaknya yang kafir yaitu Kan'an tidak termasuk keluarga, berdasarkan ayat:

b. قربى / Qurbaa

$$
\text { يا نوح إنه لبس من أهلك إنه عمل غير صالح. (هود: 7 ؟) }
$$

Shawi (1, hal : 65 ) menyebutkan bahwa qurbaa adalah keluarga yang ada hubungan kekerabatan baik yang termasuk ahli waris maupun yang tidak termasuk, yang tidak mendapat warits, tapi termasuk keluarga kekerabatan seperti pada ayat, an-Nisa: 7,

$$
\text { و إذا حضر القسمة أولو القربى (النساء: Vam }
$$
dan keluarga kerabat yang bersipat umum, yang ada hubungan kerabat dengan ibu dan bapak, seperti pada ayat al-Baqarah: 8

c. عثيرة /'Asyirah

$$
\text { وبالو الدين إحسانا وذى القربى (البقرة: A ) }
$$

Al-Raghib (hal: 375) menyebutkan 'asyirah adalah keluarga seketurunan yang berjumlah banyak, hal itu berasal dari kata عشرة dan kata itu menunjukkan bilangan yang banyak, seperti pada ayat:

Melihat dari hubungan keluarga di atas, menunjukkan sistem kekerabatan keluarga yaitu salah satu prinsip mendasar untuk mengelompokkan tiap orang ke dalam kelompok sosial, peran, kategori, dan silsilah. Hubungan keluarga dapat dihadirkan secara nyata (bapak, ibu, saudara, dll) atau secara abstrak menurut tingkatan kekerabatan. 


\section{Kontruksi Keluarga dalam Konteks Hukum Islam}

Bagaikan sebuah bangunan, keluarga dibangun dari beberapa komponen yang menopongnya. Kontruksipun harus disiapkan untuk menunjang kekuatan dan kekokohan pada bangunan keluarga. Dalam Islam begitu pentingnya kedudukan sebuah keluarga, ini dibuktikan bahwa keluarga adalah tempat pendidikan yang pertama dan utama. Melalui tempat tersebutlah seseorang mengetahui hak dan kewajiban sebagai hamba yang mempunyai tugas mengabdi kepada sang Khaliq.

Keluarga dibangun dari pertalian antara dua insan yang berbeda kemudian disatukan dalam sebuah pernikahan. Pernikahan berorientasi membentuk keluarga sakinah, yang berlandaskan cinta dan kasih sayang. Pernikahan merupakan perjanjian yang kuat antara sesama pengantin.Keluarga berada dalam pengalaman manusia. Fungsi hidup dan kehidupan seseorang, demikian pula interaksi dengan individu lain, senantiasa berada dalam fakta keluarga.

Secara bahasa nikah artinya الضمّ : menyatukan, التداخل : saling memasuki, dan digunakan pula secara majaz dengan arti الوطىئ: setebuh, العقد: aqad, ikatan. Kebanyakan penggunaannya dalam arti al-aqdu (al-Shan'ani: 3, 109). Asal arti nikah adalah al-aqdu kemudian diartikan al-Jima': bercampur (al-Raghib, 561).

Pernikahan adalah ikatan lahir batin antara seorang pria dan wanita sebagai suami istri dengan tujuan membentuk keluarga (rumah tangga) yang bahagia dan kekal berdasarkan Ketuhanan Yang Maha Esa (Hadikusuma, 2003:7). Dalam KHI Pasal 2 dinyatakan bahwa pernikahan adalah akad yang sangat kuat atau mitsaqan gholidhan untuk mentaati perintah Allah dan melaksanakannya merupakan ibadah.

Dari definisi yang ada asas atau prinsip perkawinan yaitu bertujuan untuk mewujudkan kehidupan rumah tangga yang sakinah, mawaddah, dan rahmah seperti yang termaktub dalam al-Quran surat ar-Ruum: 21

Artinya: Dan di antara tanda-tanda kekuasaan-Nya ialah dia menciptakan untukmu isteri-isteri dari jenismu sendiri, supaya kamu cenderung dan merasa tenteram kepadanya, dan dijadikan-Nya diantaramu rasa kasih dan 
sayang. Sesungguhnya pada yang demikian itu benarbenar terdapat tanda-tanda bagi kaum yang berfikir.

Pernikahan dianggap sah apa bila memenuhi syarat berikut (KHI, Bab IV Pasal 14):
a. Calon suami
b. Calon istri
c. Wali nikah
d. Dua orang saksi
e. Ijab kabul.

Adapun tujuan pernikahan dalam Islam adalah memenuhi tuntutan hajat tabiat kemanusiaan, berhubungan dengan laki-laki dan perempuan dalam rangka mewujudkan suatu keluarga yang bahagia dengan dasar cinta kasih sayang untuk mendapat keturunan yang sah. Ada beberap tujuan yang melekat dalam setiap perkawinan yaitu (1) menghalalkan hubungan kelamin untuk memenuhi hajat tabiat kemanusiaan, mewujudkan suatu keluarga dengan dasar cinta, kasih dan (3) memperoleh keturunan yang sah.

Dari rumusan di atas, Imam Ghazali membagi tujuan perkawinan dalam lima hal: (1) memperoleh keturunan yang sah dan mengembangkan suku-suku bangsa manusia, (2) memenuhi tuntutan naluriyah hidup kemanusiaan, (3) memelihara manusia dari kejahatan dan kerusakan, (4) membentuk dan mengatur rumah tangga yang menjadi basis dari masyarakat yang besar di atas kecintaan dan kasih sayang, dan (5) menumbuhkan kesungguhan berusaha mencari rizeki penghidupan yang halal dan memperbesar rasa tanggung jawab (Nur Yasin, 2008: 69-70).

Melihat dari tujuan pernikahan yang hendak dicapai, maka sebelum melakukan pernikahan seseorang harus selektif terhadap pilihan pasangannya, yang meliputi:

\section{Persiapan sebagai Suami}

a. Memilih wanita muslimah

Artinya: Orang laki-laki pezina, yang dinikahinya ialah perempuan pezina pula atau perempuan musyrik. Perempuan pezina jodohnya ialah laki-laki pezina pula atau laki-laki musyrik, dan diharamkan yang demikian itu atas orang yang beriman. (QS. An-Nuur: 3) 
Ayat ini senada dengan hadis yang menganjurkan memilih istri yang baik agamanya:

تتكح المر أة لأربع: لمالها ولحسبها وجمالها ولدينها، فاظفر بذات الدين

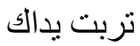

Artinya: "Wanita biasanya dinikahi karena empat hal: karena hartanya, karena kedudukannya, karena parasnya dan karena agamanya. Maka hendaklah kamu pilih wanita yang bagus agamanya (keislamannya). Kalau tidak demikian, niscaya kamu akan merugi." (HR. Bukhari-Muslim)

Jika demikian, maka ilmu agama adalah poin penting yang menjadi perhatian dalam memilih pasangan. Karena bagaimana mungkin seseorang dapat menjalankan perintah Allah dan menjauhi larangan-Nya, padahal dia tidak tahu apa saja yang diperintahkan oleh Allah dan apa saja yang dilarang oleh-Nya. Dan disinilah diperlukan ilmu agama untuk mengetahuinya.

b. Menyiapkan Mahar untuk Istri

Artinya: "Berikanlah maskawin (mahar) kepada wanita (yang kamu nikahi) sebagai pemberian dengan penuh kerelaan. ${ }^{1}$ Kemudian jika mereka menyerahkan kepada kamu sebagian dari maskawin itu dengan senang hati, Maka makanlah (ambillah) pemberian itu (sebagai makanan) yang sedap lagi baik akibatnya." (QS. An-Nisa: 4)

Dalam Kompilasi Hukum Islam disebutkan bahwa pengertian mahar adalah pemberian dari calon mempelai pria kepada calon mempelai wanita, baik berbentuk barang, uang atau jasa yang tidak bertentangan dengan hukum Islam (KHI, 2004: 9).

Calon mempelai pria wajib membayar maskawin atau mahar kepada calon mempelai perempuan dalam jumlah, bentuk dan jenis sesuai dengan kesepakatan kedua belah pihak (KHI, 2004: 21). Bahkan para ahli figh sependapat

\footnotetext{
${ }^{1}$ pemberian itu ialah maskawin yang besar kecilnya ditetapkan atas persetujuan kedua pihak, Karena pemberian itu harus dilakukan dengan ikhlas.
} 
bahwa maskawin itu termasuk syarat sahnya nikah, dan tidak boleh diadakan persetujuan untuk meniadakannya (Ibnu Rusyd,2002: 115).

Nilai yang agung dari makna ayat di atas terkait dengan mahar adalah memberikan kelapangan kepada wanita jika ia mau memberikan atau mempersilahkan untuk ikut menikmati lagi kepada suaminya, maka hal ini menggambarkan tatanan rumah tangga yang tingkat kerjasamanya dan eratnya hubungan mereka sangat baik. Sang suami boleh memakan atau menerima kembali atas kerelaan istri tanpa ada citra yang kurang baik. Nilai yang 'agung' disini adalah ketika suami memberikan maskawin dengan keikhlasan penuh tanpa berharap kembali, tetapi disaat yang sama ia masih ada kesempatan baginya menikmati harta (maskawin) itu jika istrinya menyerahkan lagi sebagiannya, maka suamai pun boleh untuk menerimanya dan menikmatinya.

c. Mempersiapkan Diri sebagai Pemimpin

Artinya: Kaum laki-laki itu adalah pemimpin bagi kaum wanita, oleh Karena Allah Telah melebihkan sebahagian mereka (laki-laki) atas sebahagian yang lain (wanita), dan Karena mereka (laki-laki) Telah menafkahkan sebagian dari harta mereka. (QS. An-Nisaa: 34).

Inilah sosok suami ideal, dialah lelaki yang mampu menjadi pemimpin dalam arti yang sebenarnya bagi istri dan anak-anaknya. Memimpin mereka artinya mengatur urusan mereka, memberikan nafkah untuk kebutuhan hidup mereka, mendidik dan membimbing mereka dalam kebaikan, dengan memerintahkan mereka menunaikan kewajiban-kewajiban dalam agama dan melarang mereka dari hal-hal yang diharamkan dalam Islam, serta meluruskan penyimpangan yang ada pada diri mereka (Ibnu Katsir, 1/653).

d. Nafkah untuk Istri 
Artinya: Tempatkanlah mereka (para isteri) di mana kamu bertempat tinggal menurut kemampuanmu. (QS. Ath-Thalaq: 6)

Ayat ini membahas mengenai wanitawanita yang ditalak, Allah perintahkan para suami untuk tidak mengeluarkan mereka dari rumahnya hingga habis masa iddah. Namun para ulama mengambil istinbath dari ayat ini bahwa wajib bagi suami untuk memberikan tempat tinggal bagi istrinya sesuai dengan kemampuannya (Husain Al Awaisyah: 5/181)

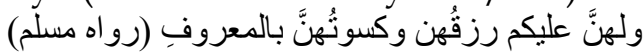

Artinya: wajib bagi kalian (para suami) memberikan rizki (makanan) dan pakaian dengan ma'ruf kepada mereka (para istri). (HR. Muslim 1218).

Para ulama berbeda pendapat mengenai kadar dari masing-masing tiga hal ini. Berapa kadar makanan yang wajib, berapa pakaian yang mesti diberikan, dan bagaimana kadar minimal tempat tinggal yang wajib. Para ulama khilaf. Namun yang tepat, batasan semua ini kembali kepada 'urf (adat kebiasaan) daerah masingmasing. Dalam Mausu'ah Fiqhiyyah Durarus Saniyyah (3/150) dikatakan:

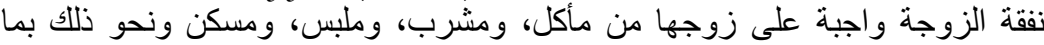

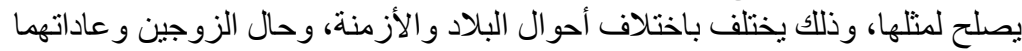

Artinya: nafkah wajib untuk istri berupa makanan, pakaian dan tempat tinggal dan yang semisal itu yang urgensinya setara. Dan hal ini berbeda-beda tergantung pada keadaan negeri dan zaman, juga tergantung keadaan kedua suami-istri dan adat kebiasaan mereka berdua.

Sebagian ulama memerinci beberapa hal lainnya selain tiga hal ini, yang dikategorikan termasuk nafkah. Dalam kitab Raudhatut Thalibin (9/40-52) disebutkan 6 hal yang termasuk nafkah:

a. Ath Tha'am (makanan pokok)

b. Al 'Udm dan sejenisnya (makanan yang menemani makanan pokok; lauk-pauk) 
Representasi Keluarga dalam Konteks Hukum Islam....

c. Al Khadim (pembantu)

d. Al Kiswah (pakaian)

e. Alaatut tanazhuf (alat-alat kebersihan)

f. Al Iskan (tempat tinggal)

Namun yang tepat, sebagaimana sudah dijelaskan, batasan cakupan nafkah ini kembali kepada 'urf (adat kebiasaan). Semisal jika memang adat setempat menganggap pembantu adalah hal yang wajib disediakan suami sebagai nafkah, maka wajib baginya menyediakan pembantu, sesuai dengan kemampuannya.

\section{Persiapan sebagai Istri}

a. Bersedia Taat kepada Suami

Seorang suami adalah pemimpin dalam rumah tangga, Sudah sepatutnya seorang pemimpin untuk ditaati. Ketika ketaatan ditinggalkan maka hancurlah 'organisasi' rumah tangga yang dijalankan. Oleh karena itulah, Allah dan Rasul-Nya dalam banyak dalil memerintahkan seorang istri untuk taat kepada suaminya, kecuali dalam perkara yang diharamkan. Meninggalkan ketaatan kepada suami merupakan dosa besar, sebaliknya ketaatan kepadanya diganjar dengan pahala yang sangat besar. Rasulullah saw. bersabda:

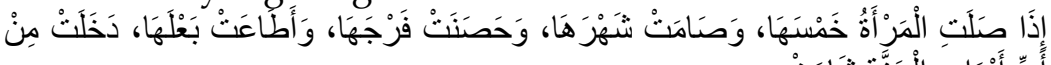

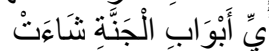

Artinya: "Apabila seorang wanita mengerjakan shalat lima waktunya, mengerjakan puasa di bulan Ramadhan, menjaga kemaluannya dan menaati suaminya, maka ia akan masuk surga dari pintu mana saja yang ia inginkan." (HR. Ibnu Hibban).

b. Menjaga Diri dan Hartanya

Rasulullah shallallaahu 'alaihi wa sallam bersabda,

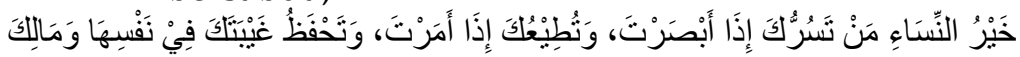

Artinya: "Sebaik-baik isteri adalah yang menyenangkan jika engkau melihatnya, taat jika engkau menyuruhnya, serta menjaga dirinya dan hartamu di saat engkau pergi." (HR. ath-Tabrani) 
Dan sungguh mengherankan sekali jika ada wanita yang tidak memperhatikan penampilan dirinya pada saat di rumahnya di mana ia sedang bersama suami, namun pada saat keluar rumah ia mempercantik diri dan menampakkan perhiasannya, sampai-sampai benarlah apa yang dikatakan oleh orang tentang perempuan seperti ini, yaitu, "Seperti kera dalam rumah akan tetapi seperti kijang bila di jalan." Oleh karena itu, takutlah engkau wahai wanita hamba Allah, takutlah kepada Allah pada dirimu dan suamimu, karena sesungguhnya suami adalah orang yang paling berhak untuk melihat dan menikmati penampilan indahmu. Janganlah engkau sekali-kali menampakkan perhiasan pada orang yang tidak boleh melihatnya, karena hal itu adalah merupakan perkara yang diharamkan (https://almanhaj.or.id/1086-hakhak-suami-atas-isteri.html).

\section{Fungsi Keluarga dalam Konteks Hukum Islam}

Dalam sebuah keluarga dituntun untuk melaksanakan atau melakukan segala sesuatu yang menjadi kewajibannya, terutama dengan lingkungan lebihlebih terhadap keluarganya. Tatkala menjalankannya, maka keluarga itu telah menjalankan fungsinya. Diantara fungsi-fungsi dari intitusi keluarga dalam konteks kehidupan adalah (Mufidah Ch, 2008: 42):

a. Fungsi biologis, perkawinan dilakukan antara lain bertujuan agar memperoleh keturunan, dapat memelihara kehormatan serta martabat manusia sebagai makhluk yang berakal dan beradab. Fungsi biologis inilah yang membedakan perkawianan manusia dengan binatang sebab fungsi ini diatur dalam norma perkawinan yang diakui bersama.

b. Fungsi edukatif (pendidikan), keluarga berkewajiban memberikan pendidikan bagi anggota keluarganya, terutama bagi anak-anaknya, karena keluarga adalah lingkungan terdekat dan paling akrab dengan anak. Pengalaman dan pengetahuan pertama anak ditimba dan diberikan melalui keluarga. Orang tua memiliki peran yang cukup penting untuk membawa anak 
menuju kedewasaan jasmani dan rohani yang bertujuan mengembangkan aspek mental spiritual, moral, intelektual, dan profesional.

c. Fungsi religious (keagamaan)

Keluarga berkewajiban mengajarkan tentang agama kepada seluruh anggota keluarganya. Keluarga merupakan tempat penanaman nilai moral agama melalui pemahaman, penyadaran dan praktek dalam kehidupan sehari-hari, sehingga tercipta iklim keagamaan di dalamnya.

Tanamkan nilai-nilai agama, pengertian halal haram, kewajiban sunnah sekaligus larangan-Nya dan beragam lainnya. Sikap inilah yang dimaksud dalam tafsir al-Quran surat at-Tahrim ayat 6 dalam menjaga keluarga dari api neraka. Apabila anak melakukan perbuatan kemungkaran atau perbuatan tercela lainnya, orang tua sangat wajib memperingatkan agar kembali ke dalam kebenaran. Begitu pula sebagai anak, bila orang tua berbuat menyalahi aturan agama, meskipun sebagai seorang anak kita berkewajiban untuk menegurnya. Sikap memberi peringatan dan menegur ini tetap harus menggunakan bahasa yang baik dan sopan.

d. Fungsi protektif (melindungi)

Keluarga menjadi tempat yang aman dari berbagai gangguan internal maupun eksternal serta menjadi penangkal segala penggaruh negatif yang masuk di dalamnya. Gangguan internal dapat terjadi dalamkaitannya dengan keragaman kepribadian anggota keluarga, perbedaan pebdapat dan kepentingan dapat memicu lahirnya konflik bahkan juga kekerasan. Kekerasan dalam keluarga tidak mudah dikenali karena berada pada wilayah privat, dan terhadap hambatan psikis, sosial, norma budaya, dan agama untuk diungkap secara publik. Adapun gangguan eksternal keluarga biasanya lebih mudah dikenali oleh masyarakat karena berada pada wilayah publik.

e. Fungsi sosialisasi

Kewajiban untuk memberi bekal kepada anggota keluarga tentang hal-hal yang berhubungan 
dengan nilai-nilai yang berlaku di masyarakat setempat. Selain itu dalam lingkungan masyarakat juga terdapat nilai tradisional yang diwariskan secara turun temurun. Proses pelestarian budaya dan adat dijalankan melalui institusi keluarga sebagai komponen terkecil masyarakat. Keluarga dalam fungsi ini juga berperan sebagai katalisator budaya serta filter nilai yang masuk ke dalam kehidupan. Fungsi sosialisasi ini diharapkan anggota keluarga dapat memposisikan diri sesuai dengan status dan struktur keluarga, misalnya dalam konteks masyarakat Indonesia selalu memperhatikan bagaimana anggota keluarga satu memanggil dan menempatkan anggota keluarga lainnya agar posisi nasab tetap terjaga.

f. Fungsi ekonomi

Keluarga merupakan kesatuan ekonomis dimana keluarga memiliki aktifitas mencari nafkah, pembinaan usaha, perencanaan anggaran, pengelolaan dan cara memanfaatkan sumber-sumber penghasilan dengan baik, mendistribusikan secara adil dan profesional, serta dapat mempertangggung jawabkan kekayaan dan harta bendanya secara sosial maupun moral.

g. Fungsi rekreatif.

Keluarga merupakan tempat yang dapat memberikan kesejukan dan melepaskan lelah serta penyegaran (refresing) dari seluruh aktifitas masingmasing anggota keluarga. Fungsi ini dapat mewujudkan suasana keluarga menjadi menyenangkan, saling menghargai, menghormati, menghibur masing-masing anggota keluarga, sehingga tercipta hubungan harmonis, damai kasih sayang, dan setiap anggota dapat merasakan bahwa rumah adalah surganya.

\section{Simpulan}

Melihat definisi yang ada tentang batasan keluarga dalam Islam, keluarga adalah satu kesatuan hubungan antara laki-laki dan perempuan melalui akad nikah menurut ajaran Islam. Keluarga Islam termasuk dalam keluarga menengah (middle family) karena bermula dari suatu 
Representasi Keluarga dalam Konteks Hukum Islam....

pernikahan yang menimbulkan kedudukan adanya orang tua, suami atau istri, saudara, dan anak.

Dalam hukum Islam suatu keluarga dibangun melalui pernikahan. Maksud pernikahan dalam hukum Islam adalah akad yang sangat kuat atau mitsaqan gholidhan untuk mentaati perintah Allah dan melaksanakannya merupakan ibadah yang bertujuan untuk mewujudkan kehidupan rumah tangga yang sakinah, mawaddah, dan rahmah.

Dari ketujuh fungsi keluarga tersebut, maka jelaslah bahwa keluarga mempunyai fungsi yang sangat penting dalam membentuk individu. Oleh karena itu keseluruhan fungsi tersebut harus terus diperhatikan. Jika dari salah satu fungsi-fungsi itu tidak berjalan, maka akan terjadi ketidakharmonisan dalam sistem keteraturan dalam keluarga. 


\section{Daftar Pustaka}

Abi Fada' Ismail, Tafsir al-Quran al-'adhim Libni Katsir, asSu'udiyah: Dar Ibnu al-Jauzi Jilid. I

Abu Ahmadi, Ilmu Sosial Dasar, Jakarta: Rineka Cipta, 1991

Ahmad Mukhtar Umar, Mu'jam al-Lughah al-Arabiyah alMu'ashirah, Kairo: Daar al-Kutub, 2008

As-Suyuthi, Shohih al-Jami' as-Shogir, Maktabah al-Islami, 1988.

As-Shawi, Hasyiah as-Shawi, Bairut: Dar Ibn 'Ashashah, 2005

Aunur Rahim Faqih, Bimbingan Dan Konseling dalam Islam, Jogjakarta: UII press, 2001

Ditjen Pembinaan Kelembagaan Islam, Kompilasi Hukum Islam, Pustaka Widyatama, Yogyakarta, 2004

Hilman Hadikusuma, Hukum Perkawinan Indonesia menurut: Perundangan Hukum Adat Hukum Agama, Bandung: Mandar Maju, 2003

Ibnu Rusyd, Bidayatul Mujtahid, Analisa Fiqih para Mujtahid, terj. Drs. Imam Ghazali Said, MA dan Drs. Achmad Zaidun, Pustaka Amani, Jakarta, 2002

Mufidah Ch, Psikologi Keluarga Islam, Malang: UIN Malang Prees, 2008

Nur Yasin, Hukum Keluarga Islam Sasak, Malang: UIN Press, 2008

Wahyu Ms, Ilmu Sosial Dasar , Surabaya: Usaha Nasional, 1986

Waryono Abdul Ghafur, Hidup Bersama al-Quran, Yogyakarta: Rihlah, 2006

Mausu'ah Fiqhiyyah Durarus Saniyyah, Jilid 3, hlm 150

https:/ / almanhaj.or.id/1086-hak-hak-suami-atas-isteri.html 